\title{
Academic Libraries and Institutional Repository: The Nigerian Polytechnics Perspective
}

\author{
Osaheni Oni (CLN) \\ Auchi Polytechnic Library, Auchi, Edo State, Nigeria \\ Kelly Odaro-Ekhaguebo \\ Lecturer, Department of Mass Communication, Auchi Polytechnic, \\ Auchi, Edo state, Nigeria \\ Aminu U. Momoh(CLN) \\ Auchi Polytechnic Library, Auchi, Edo State, Nigeria
}

\begin{abstract}
The study examined Academic Libraries and Institutional Repository in Nigeria: the Polytechnics perspective. The study pointed out that academic library has a significant role in the establishment of institutional repository in institutions of higher learning because academic libraries are best positioned to provide much of the document preparation expertise. Polytechnic libraries can most effectively provide much of the expertise in terms of metadata tagging, authority controls and other content management require in institutional repository that increases access to and usability of the data. The study highlighted the benefits polytechnics stand to gain from institutional repository to include visibility and show casing of the polytechnics to the research community. The study discussed some challenges militating against the establishment of institutional repository in Nigerian Polytechnics. The challenges discussed are lack of fund, lack of infrastructures, lack of automation and polytechnic management lack of interest in library development. The study therefore recommended that polytechnics management should ensure that library budget, library dues and other money meant for library are judiciously expended on library development such as establishment of institutional repository, library automation, and provision of internet facilities, information technology infrastructure, training and retraining of library staff. Polytechnics management should create or provide enabling environment for their libraries and librarians to embark on the establishment of institutional repository.

Keywords: Academic, Libraries, Polytechnics, Institutional Repository, Nigeria.

DOI: $10.7176 / \mathrm{IKM} / 9-9-02$

Publication date:October $31^{\text {st }} 2019$

\section{Introduction}

Before the advent of Information and Communication Technology (ICT), Libraries were the main custodian of knowledge in print format. ICT has come to revolutionize not only the ways information is packaged, processed, stored and disseminated but the way users seek and access information. As a result, libraries notably academic do no longer restrict themselves to print routine services such as collection development, cataloguing and classification, circulation, reference services, current awareness, selective dissemination of information and other bibliographic services but have incorporated ICT related services such as provision of e-books, e-journal, eperiodicals and institutional repository. Lombardi (2000) notes that library users now prefer more computer content, more and more computer indices, digital finding aids, digital repositories of articles and online access to newspapers. Crow (2002) posits that the potential impact of institutional repositories on academic libraries occurs on both the strategic and tactical levels. The establishment of institutional repository programmes in academic libraries simply means that the library seeks to move beyond the traditional ways of custodian duty to active participant in the evolution of scholarly communication. Crow describes institutional repositories as digital collections, capturing and preserving the intellectual output of a single or multi-university community. Institutional repository is a web-based database of scholarly materials which are institutionally defined (as opposed to a subject base); cumulative and perpetual (a collection of records); open and interoperable and thus collects, store and disseminates.
\end{abstract}

\section{Origin of Institutional Repository}

Institutional repository is an online resource for the storing in digital form of scholarly or academic publication such as research articles, dissertation and thesis on behalf of the institution. Institutional repositories came into existence the same time as the World Wide Web (WWW). The institutional repositories online repository was established in 1999 by a physicist called Paul Ginspan of Los Alamos of National laboratory in New Mexico. The focus was on theoretical physics. He has since expanded to include other field such as Mathematics and computer science. The success of arxiv led to the establishment of other repositories such as repec (research 
papers) in Economic, cogprint and educational line.

In 2001, Eprints software for institutional repositories was conceived. This led to development of software used for digital repositories such as Dspace launched by Massachusetts Institute of Technology in 2002. Fedora (Flexible Extensive Digital Object Repository Architecture) that started in 1997 at Cornell University's Digital Library research group as a joint venture of Cornell University of information science and university of Institutional repository Virginia library. However, the most current version was released in 2005. In 2002, institutional repository was further emerged with the publication by Raym Crow, a senior consultant for the scholarly publishing and academic resources coalition (SPARC) based in Washington, D.C. the publication was a groundbreaking paper entitled the case for institutional repositories" Crow emphasized that in additional to academic and scientific institution, non- academic institutions such as government might benefit from the maintenance of institutional repositories. In 2010, Spanish website SCIC published a list of about 400 leading Institutional Repository under the title "Ranking Web of World Repositories". The first ever institutional repository arXiv was ranked number one. However, the six of the top ten institutional repository in the world are American namely arxiv, citeseerx, scientific and Technical information network, social science Research Network, Smithsonian/ NASA Astrophysics data system and MIT Dspace (Halling, 2006).

\section{The Role of Polytechnic Libraries in Institutional Repository}

The relevance of academic libraries in institutional repository cannot be undermined. The polytechnic libraries are traditionally responsible for acquiring, processing, managing information resources to enhance teaching, learning and research development of the institution. Polytechnic Libraries have always served as access point for information. The role of polytechnic libraries have evolved from the days of closed stocks through surf browsing and card catalogue, punch cards and OPACs, to the present concept of open access and institutional repository (Cisse, 2004). Anunobi (2008) reported that a survey conducted by the coalition for network information (CNI) and United States Higher Education Institutions found that research libraries have taken on a leadership role in both policy formation and operational deployment roles for institutional repositories. Eightyeight (88\%) of the respondents indicated that the library reserved the sole responsibility. Crow (2002) articulates the role of academic libraries such as the polytechnic libraries in institutional repository as follows:

1. Polytechnic libraries can most effectively provide much of the expertise in terms of metadata tagging, authority controls and the other content management require in institutional repository that increases access to and usability of the data.

2. Polytechnic libraries are best suited to provide much of the document preparation expertise such as document format control, archival standards etc to help authors contribute their research work to institution's repository

3. Polytechnic libraries should retain the responsibility for managing and archiving published information materials.

4. It is imperative for polytechnic libraries to invest in the future, institutional repository offer a compelling response.

It is interesting to note that some Universities libraries are responding to this noble gesture. Lynch (2003) posits that university based institutional repositories manage disseminate and preserve where appropriate, digital materials created by the institution and its community members. According to Musa, Musa and Aliyu (2014) some of the universities libraries have already embarked on digitalizing of their local contents. University of Jos in 2009 became the first university to establish an institutional repository (IR) and second in West Africa after University of Science and Technology, Ghana. Kashim Ibrahim library, which is the main library of Ahmadu Bello University, Zaria started its institutional repository in July 2005. University of Nigeria Nsuka joined the trend in 2008, as it commenced the digitization of its resources. Federal University of Technology, Akure, started in 2011, using D space (application software) in managing the institutional content of their repository and Covenant University in the year 2012 becoming the first private university that owns institutional repository. Igwesi (2010) notes that Nnamdi Azikwe University, (UNIZIK) Akwa; Federal University of Technology Owerri (FUTO), and Obafemi Awolowo University, (OAU) Ile-Ife have all started digitization of it collections. Other institutional repository initiatives in Nigeria as identified by Ochai (2007) in Igwesi (2010) include: The Nigerian University Library Consortium which created the capacity for libraries to negotiate for reduced licenses for EBSCO host and it contain over 8000 academic journal in all fields. Also, the Nigeria Virtual Library Initiative by the Nigeria universities Commission (NUC) which aims at bringing electronic information to Nigerian Universities. However, Nigerian polytechnics are yet to follow suit. Polytechnics should emulate their universities counterparts by investing on the establishment of institutional repository and by extension enhances library development. We challenge Nigerian polytechnics to invest on institutional repository in order to remain relevant as research institutions. The gap between polytechnics and universities is getting wider. I think this is one of the areas polytechnics should stay closing the gap. 


\section{Benefits Nigerian Polytechnics Stand to Gain from Institutional Repository}

The benefits of institutional repository are massive, enormous and unquantifiable to institutions, libraries, librarians and scholars. An international workshop was held at Ahmadu Bello University, Zaria in 2008 on institutional repository. Nigerians and research libraries were encouraged to organize the institutional scholarly output into institutional repository in order to make the institutional research works available both nationally and internationally through open access (Bozimo, 2008). Institutions of higher learning especially polytechnics should strive to establish institutional repository. Polytechnic librarians should initiate the move for the establishment of institutional repository, since the management of institutional repository will position librarians in the mainstream of academic activities and will be a boast to their function as information managers and providers of access to recorded knowledge. Okojie (2008) opines that the paradigm would make polytechnics librarians gain leverage, leapfrog and become members of international community of researchers.

Fabunmi, Paris and Fabunmi (2006) posited that institution repository being one of the important aspects of current global information trends fits into library and information service for effective and efficient information dissemination, preservation of information resources and facilitating the integration of library services into the learning process of academic institution. Mckay (2003) enumerates the benefits of institutional repository to as follows:

$>$ Institution repository makes it possible for libraries to provide information sources electronically with it inherent values.

$>$ Institution repository improves access to library resources. By institution repository library collections, information will be accessible to all instead of a group of researchers.

$>$ Institution repository projects allow users to search for collections rapidly and comprehensively from anywhere at any time. Institution repository makes the invisible to be visible.

$>$ Several users can access the same materials the same time without hindrance.

$>$ It also removes the problems of distances, as users do not have to travel to libraries that possess the hard copies of library materials before they can access and use such materials.

$>$ Institution repository holds the advantage of providing library collection electronically; thereby improving access to library resources, the opportunity to search for collections rapidly and eliminating the issues of distances, alienating space constraints and cost of print collection (preservation and conservation of tradition library materials).

$>$ It creates visibility not only of the library's content, but the scholarly work (theses, dissertation, project work, seminar papers conferences proceedings, working papers and technical reports) within the university and raises the profile of an institution by showcasing digital collections which can be a useful public relation exercise.

The benefits of establishing institutional repository in Nigerian polytechnics will be massive. According to Wikipedia (2012) polytechnic libraries will benefit the following from institutional repository:

- Institutional repository will opens up the research output of the polytechnics to the world.

- Institutional repository will help to maximize the visibility and impact of publication output by show casing the polytechnics to research community.

- Institutional repository will enable and encourages inter discipline approaches to research facilities in the polytechnics.

- Institutional repository will enable polytechnic libraries collects and creates digital outputs.

- Institutional repository will facilitate the development and sharing of digital teaching materials and aids in the polytechnics.

- Institutional repository will support polytechnics students' interest by providing access to theses, dissertations, projects, seminar or conference papers and journal articles of their lecturers and other researchers.

- Institutional repository is one of the criteria for the webometric ranking or rating of institutions. Nigerian polytechnics must take advantage of this.

\section{Challenges facing the Establishment of Institutional Repository in Nigerian Polytechnics}

From our observation many Nigerian polytechnics if not all have not yet fully keyed into open access institutional repository despite the numerous benefits. The following factors are militating against the establishment of institutional repository in polytechnics libraries in Nigeria. Usman (2007) points out some of the challenges to include: inadequate funds, lack of digitization equipment, inadequate knowledge and skills, lack of institutional policy and lack of electricity support. Mutula and Ojedoku (2008) identified severe financial constraints, inadequate infrastructure (i.e. electricity, telephone line, building etc.), outdated staff training opportunities and facilities, harsh environmental conditions, acceleration equipment degradation, inadequate salaries and difficult working conditions, and inadequate skills in strategic planning and in grant proposal for 
Digital Library Projects as some of the challenges of digital library development in African.

Stafan (2001) advocated for the allocation of adequate fund for the digital conversion by the appropriate authorities. A financial constraint has been a bane to effective and efficient management of library; hence the need to put into consideration adequate source of fund and funding. Most polytechnic libraries do not have the basic information technology infrastructures or facilities that would facilitate the establishment of institutional repository. Lack adequate funding had been a hindrance to library development in developing countries. Despite the shrinking budgetary allocation to polytechnic libraries, the libraries do not even have access the money neither are they aware of the availability of such funds. In Nigeria, students pay the library fees alongside with school fees but the institution management in most cases do not used the money for library development. If not Tertiary education Trust fund (TETFUND) even though librarians are not fully involved in the award of contract, most polytechnic libraries in Nigeria would have been in shamble.

Some Nigerian polytechnic libraries do not have website, facebook account, e-mail address, enough computers, Wi-Fi (internet connectivity), server etc. Internet facility is a general factor in accessing information and knowledge in this $21^{\text {st }}$ century. Management of polytechnics in Nigeria should provide these facilities as top priority (Okoye \& Ejikeme). A perennial problem in many universities is that not all researchers may have their own computer, or one that is linked to the University network, or one with the right software on that computer (Chibini, 2011). Some Nigerian polytechnics management are not interested or committed to library development. It is no longer secret that some lecturers and non- academic staff in Nigerian polytechnics do not use the library; they do not have knowledge of the resources in the library in their own field. Some management staff cannot articulate the objectives of the library in the institution and as a result, they would always vote against any developmental plan of the library on the ground that is a waste of the limited fund.

Technophobia has led to the delay in the application of ICT in performing library services in Nigeria. The new information revolution in librarianship has provided a unique platform for speedy provision and dissemination of information. This highly celebrated technology in librarianship has also created some distresses. This technological change could be resisted due to fear. This fear, which is known as techno-phobia or computer phobia could have an adverse effect on the productivity of both male and female library staff (Ekuoye, Oni \& Momoh, 2015). Chidi and Oyeronke (2011) opined that the departure from the manual methods of carrying out library services has without a doubt improved the quality of service offered by the library to its clientele and it has also on the other hand brought about a reasonable degree of techno-stress experienced by professional librarians while carrying out library services

Lack of automation in most polytechnic libraries in Nigeria has hampered the establishment of Institutional repository. Automation of library is a sine-qua-non to the establishment of Institutional repository. Some librarians in academic are not ICT compliance. They cannot operate computer, use internet, social media etc. as a result, they do not support any I T driving policy and programme. Baro, Oyeniran \& Ateboh (2013) posited that among the major challenges facing digital library projects in Africa has been the readiness of academic libraries in terms of skills and knowledge to implement digital library services. Rosenberg (2006) averred that skills in eresources management, e-service development, full-text digitization and teaching skills are lacking in African University Libraries. Polytechnic libraries are even worse. Information and communication technology skills in Nigerian tertiary institution face a lot of challenges. Adomi and Anie (2006) posited that insufficient number of computer and peripherals devices inhibit deployment and use of I.C.T. Safahieh and Asemi (2008) assessed the computer literacy skill of librarians in Isfahan University of Iran. The results indicated that majority of the librarians have acquired their computer skill through informal channels. The most common problem cited in computer usage was frequent breakdown of system, electric power failure, and inadequate computers in the libraries and librarians' inadequate computer skills. Ramesh, Babu, Vinayagamoorthy and Gopalakrishnan (2007) conducted a study of ICT skills among librarians in engineering educational institutions in Tamil Nadu to identify the types of ICT skills, assess the level of skill, the means of acquiring ICT skills and identify the constraints in acquiring such skills by the librarians. The study found that the librarians of these institutions have acquired basic skills in ICT, but they lacked knowledge about network-based services and digital library services.

\section{Conclusion}

Libraries and librarians have been at the centre of providing access point to print institutional resources. Academic libraries are the focal point for teaching, learning and research in institutions of higher learning. Wellestablished academic libraries can cater for print and electronic resources. Academics are already used to publishing for professional recognition, career advancement as well as contributing to knowledge advancement in their respective field of endeavour. Establishment of institutional repository in polytechnic libraries will give a global visibility to scholarly publications of the polytechnics. Institutional repository is a way of reducing the cost of scholarly publications and increasing visibility and access to research from lecturers and students of the polytechnics by hosting them in the polytechnic libraries institutional repository website. The relevance of 
institutional repository to institutions of higher learning is numerous. Institutional repository is one of the criteria for the webometric ranking or rating of institution apart from visibility and recognition.

\section{Recommendations}

1. Polytechnic management should ensure that library budget, library dues and other money meant for library are judiciously expended on library development such as establishment of institutional repository, library automation, and provision of internet facilities, information technology infrastructure, training and retraining of library staff.

2. Librarians on their part should try as much possible to overcome technophobia syndrome in order to effectively and confidently pursue the establishment of institutional repository.

3. The polytechnic management and library administrator should develop appropriate copyright mechanism to avoid unnecessary infringement.

4. Polytechnics management should create or provide enabling environment for their libraries and librarians to embark on the establishment of institutional repository.

\section{References}

Adomi, E.E \& Anie S.O (2006). An assessment of computer literacy skills and professional in Nigerian university libraries. Library Hi tech news, 23(2): 10-14.

Anunobi, C.V.\& Okoye, I.B. (2008). The Role of Academic Libraries in universal Access to and Electronic Resources in the Developing Countries. Library philosophy and practice

Baro, E.E Oyeniran, K.G., Ateboh, B. (2013). Digitization projects in University libraries in Nigeria: the journey so far. Library Hi Tech News, 9:.21-36.

Bozimo, D.O. (2008). Strategic Approach to Open Access in Nigeria. An international Workshop on the Open access repositories: New model for Scholarly communication. Retrieved from http://www.prereleasepoint.com(200805)12-strateg.

Campbell, J.D. (2006). Changing a cultural icon: The academic library as a virtual destination. Educause Review 41(1), 16-31

Chibini, V.M. (2011). Use of electronic journals by academic staff at Strathmore university. A Thesis submitted in partial fulfillment of the requirements for the Degree of Master of Philosophy in Information Sciences.

Chidi, I \& Oyeronke, A.(2011). The Impact of Technostress on Librarians: A Survey of Covenant University Library. The Information Manager, 11 (1\&2)

Cisse, C. (2004). Access to electronic information and information research. SCAULWA Newsletter, 5(1), 1417

Crow, R. (2002). The case for institutional repositories: A SPARC position paper. Washington: Scholarly publishuing \& Academic Resources Coalition.

Ekuoye, O, Oni \&Momoh, U.A (2015). Gender and Techno-Phobia among Library Staff in Some Selected Polytechnic Libraries in South-South Region of Nigeria. Pyrex Journal of Library and Information Science, 1 (3): 13-19. Retrieved from http://www.pyrexjournals.org/pjlis

Fabunmi, B.A Paris, M., Fabunmi, M. (2006) Digitization of library resources: challenges and implication for policy and planning. International journal of African and American Studies. 5(2):29.

Halling, C. (2006). History of the institutional repository. Retrieved from http://www.ehow.com/about_6693254 history-institutional-repository.html\#ixzz25mqonLHG

Igwesi, U. (2010). Status of digitization of Federal University Libraries in South-Eastern Zone of Nigeria. (Unpublished master dissertation project). University of Nigeria, Nssuka.

Library of Congress (2009). Library of congress challenges to building an effective digitallibrary.Retrievedfrom:http://www.memory.loc.gov/amen/dliz/html/cbed/ht $\mathrm{ml}$..

Lombardi, J.V. (2000). Academic libraries in a digital age. D-Lib Magazine 6(10)

Mckay, S. (2003). Digitization in an Archival Environment. Electronic Journal of academic and Special Librarianship, 4(1).

Musa A.U., Musa, S. (2012). Digitization of library resources in Kashim Ibrahim Library: processes, Challenges and the Impact on the services of the library. A paper presented at Kaduna State Chapter of NLC/AGM $\quad 12^{\text {th }}$ December $2012 . \quad$ Retrieved from: http://www.researchgate.net/publication/286936035.

Mutula, S.M \& Ojedokun, A.A (2008) Digital libraries. In Aina, L.O. et al., (eds). Information and knowledge management in the digital age: concepts, Technologies and Africa perspectives Ibadan: Third World Information Service.

Ochai, A. (2007). Modern trends in the provision and use library resources through digitization. A keynote address at the National workshop on digitization of library materials: process and tools at the computer centre, University of Jos 
Okoye, M.O. \& Ejikeme, A. N. (2011). Open access, Institutional Repositories and Scholarly Publishing: The Role of Librarian in South Eastern Nigeria. Library Philosophy and Practice

Okojie V. (2003). Strategic approach to open access in Nigeria. An internatiomnal workshops on the open access repostries: New model for Scholarly communication. Retrieved from http://www.prereleasepoint.com(200805)12-strateg.

Rosenberg, D. (2006). Toward the digital in Africa. Electronic Library, 24 34: 289 - 293

Stefano, P (2001). Selection for digital conversion in academic libraries. College and research libraries, 62, $58-$ 69.

Usman, I.A Lyin, A.M. (2007). Greenstone Digital Library Software: the librarians' role. Paper presented at the national workshop on digitization of library materials: process and tools organized by the National Library of Nigeria, at the University of Jos, Jos, Plateau State.

$\begin{array}{llll}\text { Wikipedia, } & \text { (2012).Institutional } & \text { Retrieved } & \text { from }\end{array}$ http://en.wikipedia.org/w/index.php?title=institutinal repository\&oldid=509775909 